\title{
An examination of assessment practices in colleges of business at various Middle East countries compared to the USA
}

\author{
Nitham M. Hindi* \\ Department of Accounting and Information Systems, \\ College of Business and Economics, \\ Qatar University, \\ P.O. Box 2713, Doha, Qatar \\ Fax: 974-4403-5001 \\ E-mail: nhindi@qu.edu.qa \\ *Corresponding author
}

\section{Mohammad K. Najdawi and Hend Abdalrahman Al Muftah}

College of Business and Economics,

Qatar University,

P.O. Box 2713, Doha, Qatar

Fax: 974-4403-5001

E-mail:monaj@qu.edu.qa

E-mail: hjolo@qu.edu.qa

\begin{abstract}
This study reports the results of a survey conducted during 2007 which was mailed to deans of schools of business at institutions of higher education located within the USA and the Middle East. Schools of business are now more engaged in assessment activities than a few years ago. Assessment activities are more costly and more emphasis seems to be placed on assessing communication skills, critical thinking, and professional knowledge. Colleges of business are relaying heavily on course-embedded measures, followed by indirect measures of assessment. Curriculum and instructional changes were the top-ranked uses of assessment results. Although almost the same percentage of colleges of business in 2007 has specific curriculum/programme objectives as they did in 1999 (92\% in 2007 and 88\% in 1999), significantly more US colleges actually assess their objectives. While $65 \%$ of the US institutions reported assessment activities annually, only $25 \%$ of Middle Eastern universities assessed their curriculum annually.
\end{abstract}

Keywords: assessment; assurance of learning; higher education; USA.

Reference to this paper should be made as follows: Hindi, N.M., Najdawi, M.K. and Al Muftah, H.A. (2011) 'An examination of assessment practices in colleges of business at various Middle East countries compared to the USA', Int. J. Management Development, Vol. 1, No. 1, pp.40-59.

Biographical notes: Nitham M. Hindi is an Accounting Professor and the Dean of the College of Business and Economics, Qatar University. He has published in the areas of financial accounting, banking, cost accounting, and 
communication. His published work can be found in Journal of Computer Information Systems, Journal of Accounting and Finance Research, Journal of Education for Business, Journal of Bank Taxation, Global Business and Finance Review, Journal of Information Systems Education, Review of Business Information Systems, and Studies in Business and Economics.

\begin{abstract}
Mohammad K. Najdawi is a Professor of Management in the College of Business and Economics at Qatar University. His areas of interest include supply chain/value chain management, e-business/e-commerce, international business logistics, production scheduling, production and operations management, decision analysis and computer applications, management information systems, systems analysis and design, and expert support systems. His published work can be found in the Communications of the ACM, Human Systems Management, Journal of End User Computing, Project Management Journal, European Journal of Operation Research, Management Science and Journal of Business Logistics.

Hend Al Muftah is an Assistant Professor of Human Resources Management of Management and Marketing Department, and serves as the Director of Human Resources Department at Qatar University. Her main interest includes human capital issues in the perspective of human resources, mainly training and education, in addition to other management issues as labour turnover, performance appraisal and recruitment.
\end{abstract}

\title{
1 Introduction
}

Educational institutions encounter an increasing challenge to justify use of human and financial resources and provide assurance that educational experiences are worthwhile in terms of student learning and preparation for professional careers. Therefore, faculty and administration personnel search for ways to assure stakeholders that college experiences add value to students. With increasing complexity and uncertainty, stakeholders are having increasingly greater performance expectations. Consequently, the concept of assessment appears to be receiving attention as a worthwhile approach to measurement of learning outcomes.

Colleges of business that are either accredited by specialised business accrediting agency or pursuing such accreditation are required to assess their degree programmes. Effective assessment of student learning is a critical step toward achieving quality. The purpose of the paper is to present perceptions of business deans regarding their assessment programmes. This paper proceeds as follows. The paper reviews relevant literature regarding assessment in the USA and the Middle East, explains the methodology utilised, discusses results, presents summary and conclusions.

\section{Literature review}

Educational assessment practices serve to compare outcomes against standards with a goal of improving student learning (Gainen and Locatelli, 1995). As noted by Evans (2002), components focus on assessing educational goals, determining various types of measurements, and deciding on specific types of assessments with a concentration on 
institutions, programmes, or classrooms. Terenzini (1989) observed an absence of precise meaning for the word 'assessment' and noted views ranging from reviews of general education to surveys of stakeholder groups and institutional self studies. Bender and Schuh (2002) summarises higher education dilemma concerning assessment by noting "institutions of higher education need strategically developed indicators that provide an honest assessment of how an institution is doing and where it is heading". They argue, however, that there is no consensus as to the best practices of measuring students' learning outcomes.

Figure 1 The assessment process (see online version for colours)

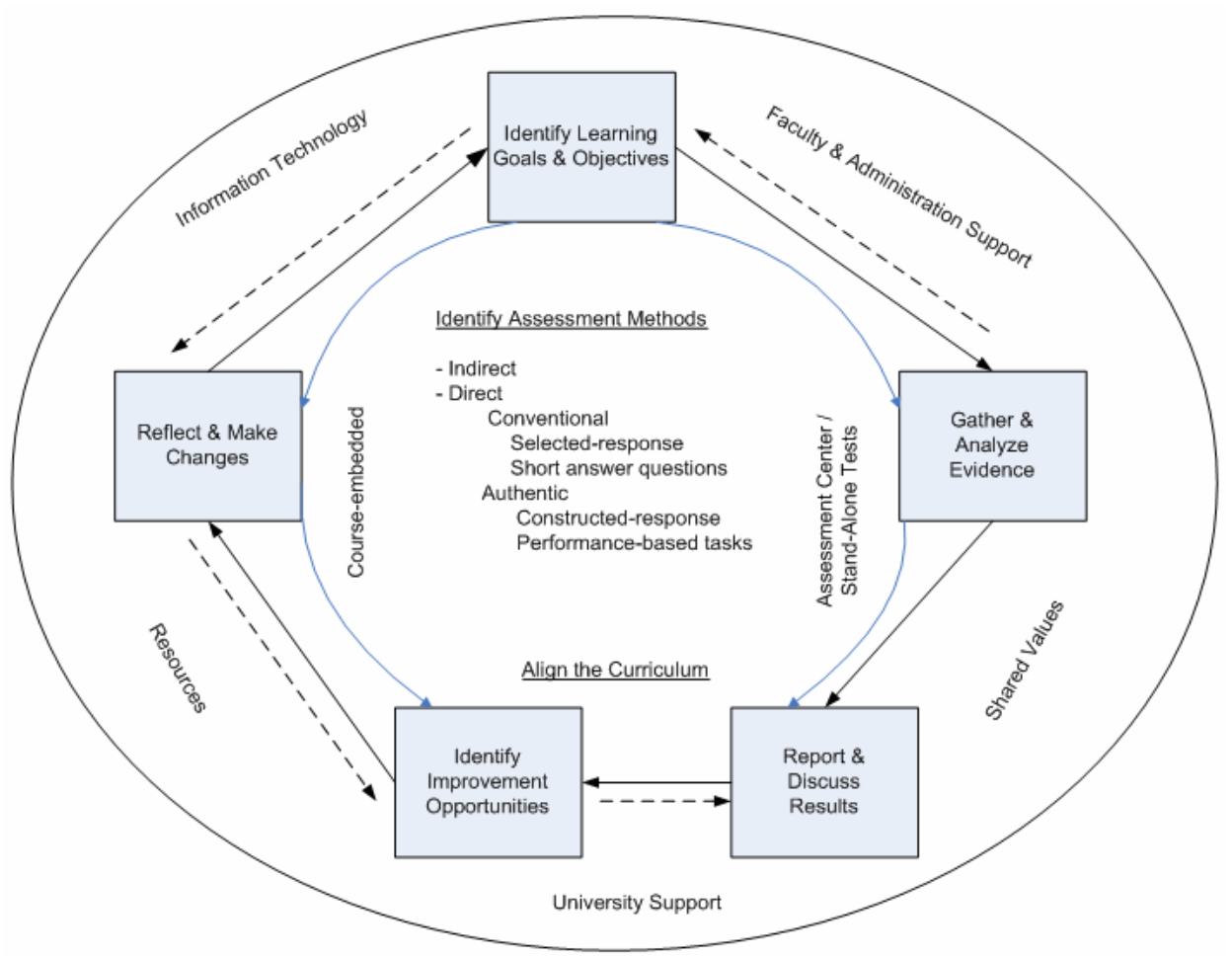

Source: AACSB (2005)

Definition and process of assessment are critical. Angelo (1995) defined assessment as an "ongoing process aimed at understanding and improving student learning". Therefore, the ultimate outcome of assessment is improved student learning. AACSB (2005) described the assessment process to include the five activities identified by Association to Advance Collegiate Schools of Business' (AACSB) Assessment Resource Centre (AACSB, 2004), including identify learning goals and objectives, gather and analyse evidence, report and discuss results, identify improvement opportunities, and reflect and make changes. Figure 1 summarises the assessment process, including the enablers to assess effectively (faculty, administrators, shared values, university support, resources, and information technology). 
Over the years, numerous factors influenced development of assessment practices that prevail in today's educational environment. Bock et al. (1982) traced inception of the relationship between assessment and accountability to the early 1960s. Hatfield and Gorman (2000) observed that the basics of prevailing approaches to assessment originated in the 1930s, were adopted by business organisations after World War II, and came to the forefront in academia in the 1980s. During the 1990s, further interest in assessment evolved as accreditation organisations initiated requirements for assessment plans. In practice, external pressures combined with internal desires for continuous improvement influenced development of assessment programmes. For example, Stivers et al. (2000) noted that the public expressed interest in a 'valued' return on tax revenues allotted to higher education.

Rapid technological changes, growing marketplace uncertainties, and increasing competitiveness predominate in today's business challenges. As a result, higher education encounters the need to prepare graduates who can function effectively in this 'real world' of business. As noted by Pfeffer (2002), "people and how we manage them are becoming more important because many other sources of competitive success are less powerful than they once were". Consequently, business schools need to focus on assuring that students possess relevant learning experiences necessary for successful professional careers.

Assessment information served to provide relevant feedback to promote quality outcomes (Dietel et al., 1991; Lambrecht, 2000; Riggio et al., 2003). While policymakers assess to establish standards, allocate resources, and develop policies, administrators focus on gaining insights into strengths and weaknesses of programmes; finally, professors emphasise the importance of improving instruction and assisting students to learn. Miller (1999) argued that accountability necessitates that the major concern of assessment and faculty involves measurement as well as certification of knowledge levels attained by students. However, James (2003) reported gaps between institutional policies and actual assessment practices and noted a potential overemphasis on higher education's 'sorting and certification' role.

For many years, accreditation agencies stressed 'inputs' and concentrated on commitment of institutional resources to assessment, rather than measurement of outcomes (Henninger, 1994). The most-recent AACSB standards include greater emphasis on the role of assessment and assurance that various learning standards are met (Hazeldine and Munilla, 2004). AACSB's (2002) management education at risk report indicated several areas of concern for business educators; curricula relevance, programme innovations, and alliances/networks of education providers. AACSB initiatives merit consideration, as it is considered to be a most-prestigious accreditation association (Roller et al., 2003).

Harwood and Cohen (1999) categorised four types of assessment practices (outcomes, classroom, graded assignments/examinations, and monitoring classroom environments) with only the outcomes approach being controlled by administrators. Kimmell et al. (1998) surveyed a national sample of accounting programmes and found that employer satisfaction, job-placement rates, achievements of recent graduates, and pass rates on certification exams were most useful outcome-assessment measures. Also, they noted that responsibility for assessment programmes was commonly not controlled by accounting/college faculty. Apostolou (1999) reviewed assessment literature and observed that a majority of authors recommended multiple measures with additional efforts directed toward usage of valid and reliable assessment instruments. Black and 
Duhon (2003) noted that standardised tests facilitate assimilation of comparative data among schools and benefit from development by persons who are testing experts.

Frequency of use and perceived effectiveness of student assessment methods were the focus of a national business-school survey by Michlitsch and Sidle (2002). Top-utilised methods included case studies, observation of student group processes, and item analysis of multiple-choice questions. Seemingly, student backgrounds and academic majors can impact assessment results. As reported by Pritchard et al. (2004), quantitative skills vary among students majoring in different business disciplines. Compared to marketing and management majors, accounting and finance majors tended to possess better quantitative abilities.

To determine various usages of assessment outcomes, Hindi and Miller (2000a) surveyed chairs of accounting departments at US colleges and universities. Top-ranked uses of assessment included curricular changes (74\%), instructional changes $(67 \%)$, and meeting responsibility to students $(63 \%)$. Highly-used purposes of assessment were to monitor programme effectiveness $(85 \%)$ and guide planning/improvement efforts $(82 \%)$. Major assessment instruments were exit surveys/interviews (71\%) and student evaluations (71\%). In another study, Hindi and Miller (2000b), sought responses from deans of US business schools. Top-ranked purposes of assessment were to monitor programme effectiveness $(91 \%)$ and guide planning/improvement efforts $(88 \%)$. Primary uses of assessment outcomes involved making curricular (89\%) and instructional $(80 \%)$ changes.

Peterson and Einarson (2001) reported results of a survey mailed to all postsecondary institutions in the USA. Respondents used traditional methods of assessment (such as standardised instruments) to a greater extent than other methods (such as portfolios). A majority of the institutions had little documentation of the extent to which assessment influenced decision processes or made pronounced impacts on key stakeholder groups. While associate of arts colleges were most apt to use student assessment results for academic planning, policies that encouraged faculty/student participation in assessment endeavours were more prevalent at the baccalaureate-granting institutions.

In practice, stakeholders have differing perspectives and expectations for assessment outcomes (Donald and Denison, 2001). Also, alignment of assessment activities with university goals can represent a complex endeavour with most-common approaches emphasising assessment on reputation and resources. Linn (1993) observed that assessment outcomes can evidence need for change and, in addition, serve as instruments for reform. Consequently, initiatives will likely continue to emphasise methodologies that seek to identify and consider performance measurements having potential to help assure progress toward continuous quality improvement.

In the Middle East area, formal assessment of programmes is somewhat a new concept. Shaw et al. (1995) reported that "although the concern for assessment currently sweeping the West is not so pronounced in the Gulf". Some universities in the Middle East assess particular portions of their operations, such as registration and advising (Abouchedid and Nasser, 2002), university training of occupational attainment (Nasser and Abouchedid, 2005), and e-learning challenges in the Arab World (Abouchedid and Eid, 2004). 


\section{Methodology}

A questionnaire (Appendix A) was based on a recommended assessment model developed by the Accounting Education Change Commission (Gainen and Locatelli, 1995). The draft was then reviewed by administrative colleagues for content analysis. The revised questionnaire was mailed to 662 deans of business schools listed in 2006 AACSB international membership directory and 68 deans from various schools in the Middle East. A total of 101 deans from US institutions and 35 deans from Middle East universities completed and returned the surveys for a response rate of $19 \%$. The survey solicited relevant information concerning assessment practices from deans of business schools at colleges and universities located in the USA and the Middle East.

The three-page questionnaire asked respondents for some demographic information such as the highest degree awarded, type of institution (public/private), and the type of business accreditation [AACSB, Association of Collegiate Business Schools and Programmes (ACBSP), regional, or Ministry of Higher Education]. Then, the survey inquired whether universities and business schools had formal assessment programmes and, if so, the title of the person(s) responsible for them and the how often they conducted their assessment activities.

The second page asked respondents to indicate the costs of assessment, and the existence of budget allocated for assessment. In addition, the survey requested information about curriculum/programme objectives and whether these objectives were assessed. Finally, participants were asked to identify their assessment approaches, assessment instruments, and usages of assessment. The third page of the questionnaire included questions related to purposes of assessment, stakeholders of business schools, and skills/competencies assessed. Finally, the respondents were asked to identify the major strengths and weaknesses of their assessment programmes, and whether business schools planned to revise/improve the programmes, and a list of anticipated improvements

\section{Results}

Table 1 summarises demographic data concerning the type of institution, highest degree awarded, and the type of accreditation. The respondents included 94 (69\%) public and 42 (31\%) private universities/colleges. Nineteen (14\%) of the respondents indicated that the baccalaureate degree was the highest degree offered; 79 (58\%) colleges and universities offered masters degrees; and 38 (28\%) institutions offered doctorate degrees. Of the 136 schools responding to the survey, $89(66 \%)$ were accredited by AACSB; seven $(5 \%)$ were accredited by ACBSP; 11 (8\%) schools were accredited by regional accrediting agencies; and $28(21 \%)$ schools are accredited by the ministry of higher education (in the Middle East, most schools are accredited by such a body). Of those schools accredited by AACSB, 41 (46\%) had separate accounting accreditation.

Of the 136 respondents, 101 respondents $(74 \%)$ noted that their colleges or universities had formal assessment programmes. One hundred and sixteen respondents (93\%) stated that their schools of business had formal assessment programmes. Directors of assessment (33\%) and vice presidents (24\%) were mentioned the greatest number of 
times to be responsible for the university assessment programmes. Sixty-one percent indicated their assessment is conducted annually, followed by $16 \%$ conducted every semester. Associate deans (31\%), assessment committee (23\%), and dean $(23 \%)$ were most frequently mentioned as having the responsibility for the school of business assessment programmes.

Twenty-nine $(26 \%)$ of the deans responded that the annual expense for schools of business assessment programmes was less than $\$ 5,000$. Thirty-six (32\%) colleges or universities indicated costs in the range of $\$ 5,001-\$ 10,000 ; 24(21 \%)$ schools were in the range of $\$ 10,001-\$ 20,000$; and at $24(21 \%)$ institutions, costs were higher than $\$ 20,000$. Sixty-six of the respondents (57\%) indicted the existence of a budget allocated for assessment activities. Seventy-four percent of those that had budget allocation their allocation were part of their college budget while $21 \%$ was a university budget.

When asked about specific curriculum/programme objectives, 117 (93\%) deans responded affirmatively, but only $108(92 \%)$ of the schools actually assessed these objectives. However, $92(81 \%)$ respondents plan to improve/revise their assessment programmes. The top five improvements/revisions planned by the schools of business included continuously review and improve of assessment process, increase formality of assessment programme, incorporate more direct measures of assessment, close the loop, and assessing learning outcomes.

Table 1 Demographic data

\begin{tabular}{lcc}
\hline & Frequency & Percent \\
\hline Location of institution & 101 & 74 \\
USA & 35 & 25 \\
Middle East & 114 & $100 \%$ \\
& & \\
Type of institution & 94 & 69 \\
Public & 42 & 31 \\
Private & 114 & $100 \%$ \\
& & \\
Highest degree awarded & 19 & 14 \\
Bachelors & 79 & 58 \\
Masters & 38 & 28 \\
Doctorate & 114 & $100 \%$ \\
& & \\
Type of accreditation & & 66 \\
AACSB international-the association to advance & 89 & 5 \\
Collegiate Schools of Business & 7 & $100 \%$ \\
Association of Collegiate Business Schools and & & \\
Programmes (ACBSP) & 11 & \\
Regional accreditation & 28 & \\
Ministry of higher education & 113 & \\
& & \\
\hline
\end{tabular}

Note: $\mathrm{n}=114$ 
An examination of assessment practices in colleges of business

Table 2 Usages, purposes, instruments, and stakeholders of assessment in schools of business

\begin{tabular}{|c|c|c|}
\hline & Number of respondents & Percent \\
\hline \multicolumn{3}{|l|}{ Usages of assessment } \\
\hline Curricular changes & 115 & 91 \\
\hline Instructional changes & 104 & 83 \\
\hline Meet responsibility to students & 74 & 59 \\
\hline Meeting responsibility to public & 56 & 44 \\
\hline Other & 12 & 10 \\
\hline \multicolumn{3}{|l|}{ Instruments } \\
\hline Student evaluation of faculty & 106 & 84 \\
\hline Alumni survey & 95 & 75 \\
\hline Exit survey/interview & 92 & 73 \\
\hline Employer survey & 76 & 60 \\
\hline Score on standardised tests & 73 & 58 \\
\hline Focus groups & 41 & 33 \\
\hline Faculty survey & 37 & 29 \\
\hline Other & 15 & 12 \\
\hline \multicolumn{3}{|l|}{ Approaches to assessment } \\
\hline Course-embedded measurement & 116 & 93 \\
\hline Indirect measures & 107 & 86 \\
\hline Stand-alone testing & 74 & 59 \\
\hline Student selection & 55 & 44 \\
\hline Other & 10 & 8 \\
\hline \multicolumn{3}{|l|}{ Purposes of assessment } \\
\hline Meet accreditation agency requirements & 112 & 89 \\
\hline Monitor the effectiveness of the program & 111 & 88 \\
\hline Guide planning and improvement efforts & 107 & 85 \\
\hline Increase accountability & 85 & 67 \\
\hline Provide information relevant to policies & 53 & 42 \\
\hline Attract better students & 45 & 36 \\
\hline Attract equipment/financial resources & 17 & 13 \\
\hline Other & 3 & 2 \\
\hline \multicolumn{3}{|l|}{ Stakeholders } \\
\hline Faculty & 115 & 91 \\
\hline Current students & 11 & 88 \\
\hline Employers & 111 & 88 \\
\hline Business community & 99 & 79 \\
\hline Alumni & 92 & 73 \\
\hline Administrators & 86 & 68 \\
\hline Prospective students & 76 & 60 \\
\hline Program advisory councils & 50 & 40 \\
\hline Staff & 49 & 39 \\
\hline Legislators & 36 & 29 \\
\hline Other & 3 & 2 \\
\hline
\end{tabular}


Table 2 summarises the responses concerning usages and purposes of assessment, approaches and instruments of assessment, and stakeholders. Approaches to assessment included course-embedded (93\%), indirect measures $(86 \%)$, and stand-alone testing $(59 \%)$. The most widely used instruments were students' evaluation of faculty $(84 \%)$, alumni survey $(75 \%)$, exit survey $(73 \%)$, employer surveys $(60 \%)$, and scores on standardised tests $(58 \%)$. Over $70 \%$ of the respondents considered the most important stakeholders of school of business to be faculty, current students, employers, business community, and alumni. Other stakeholders mentioned included administrators, prospective students and programme advisory councils.

Most schools (91\%) used assessment outcomes to make curricular changes, followed by instructional changes ( $83 \%)$, and as a means for meeting responsibility to students $(59 \%)$. The three most-mentioned purposes for assessment included meeting accreditation requirements $(89 \%)$, monitoring programme effectiveness $(88 \%)$, and guiding planning and improvement efforts $(85 \%)$. It is interesting to note that comparatively fewer schools of business used assessment to justify/attract financial resources, attract better students, or provide information relevant to policies.

Table 3 summarises the responses to the specific skills/competencies assessed by schools of business. Communication skills, critical thinking, professional knowledge, technology/computer usage, global issues, and problem solving were the top six skills mentioned by the deans. Least-assessed skills included lifelong learning, reflective thinking, multicultural/diversity issues, and interpersonal skills. These skills are more difficult to measure, which may be a reason they were less frequently mentioned.

Table $3 \quad$ Skills/competencies assessed by schools of business

\begin{tabular}{lcc}
\hline Skills/competencies & Number of respondents & Percent \\
\hline Communication skills & 117 & 93 \\
Critical thinking & 110 & 87 \\
Professional knowledge & 105 & 83 \\
Technology/computer usage & 95 & 75 \\
Global issues & 89 & 71 \\
Problem solving & 87 & 69 \\
Professional integrity/ethics & 86 & 68 \\
Interpersonal skills & 66 & 52 \\
Multicultural/diversity issues & 56 & 44 \\
Reflective thinking & 52 & 41 \\
Lifelong learning & 34 & 27 \\
Other & 2 & 2 \\
\hline
\end{tabular}

Survey participants were asked to identify the strengths and weaknesses of their assessment programme. When asked to identify the strengths of assessment, participants mentioned thorough and comprehensive assessment programme, the use of direct assessment measures, link to mission, goals, and outcomes, constant review of outcomes to ensure quality of curriculum/programmes, and faculty commitment. Major weaknesses related to lack of time and resources, lack of systematic planning of assessment/limited scope, lack of faculty involvement, assessment measures need improvements, and the need to close-the-loop. 
Table 4 Summary of calculated chi-square values for selected variables

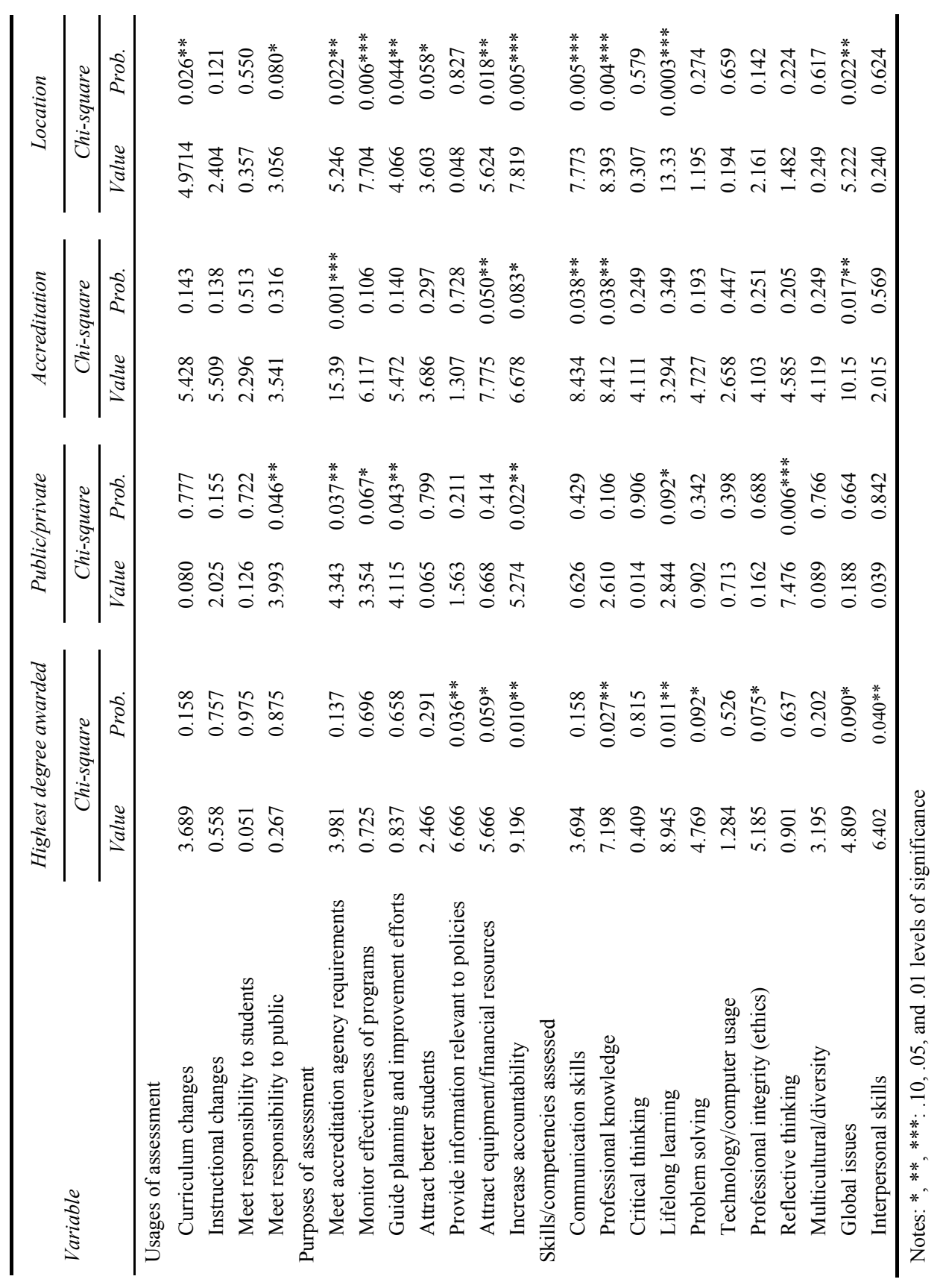


The chi-square non-parametric test was used to determine whether various relationships were statistically significant. Table 4 presents a summary of calculated values for various chi-square tests involving assessment variables (usage of assessment, purposes of assessment, and skills/competencies assessed) and characteristics of business schools (highest degree awarded, type of institution (public or private), business accreditation status, and location (USA vs. Middle East). While a lack of significance was noted for the majority of calculations, several significant relationships were apparent.

There was a statistically significant relationship between highest degree awarded and purposes of assessment. Universities that awarded only bachelor degrees were almost three times more likely than doctorate granting institutions and twice more likely than Master I institutions to identify 'provide information relevant to policies' and twice more likely than doctorate granting institutions to select 'attract equipment and other financial resources' as primary purposes of assessment. Colleges that are Master I were more likely than colleges that either bachelor only or doctorate granting in selecting 'increase accountability' as primary purpose of assessment. Colleges that only offer bachelor degrees were five times more likely than doctorate granting universities and almost twice more likely than Master I institutions to assess life long learning. Master I institutions were more likely to assess global issues, problem solving, professional integrity (ethics), professional knowledge, and interpersonal skills.

There was a statistically significant relationship between type of institution (public vs. private) and meet responsibility to the public. Not surprisingly, public institutions were more likely than private institutions to identify 'meet responsibility to the public' as a primary usage of assessment. Private institutions were more likely to assess lifelong learning and reflective thinking than public institutions. However, there were no statistically significant relationships between the type of college (public/private) and purposes of assessment. Public universities were more likely to have AACSB accreditation than private universities. Public universities were more likely to have AACSB accreditation than private universities. Private universities were more likely than public institutions to have ACBSP accreditation. Seventy-five percent of public universities and $71 \%$ of private universities reported the existence of a formal assessment programme at the university level. Almost all colleges of business had a formal assessment programme (95\% of public universities and $88 \%$ of private universities). Public universities reported that associate dean was responsible for assessment at their college of business level compared to their dean at private institutions. Public universities were more likely than private universities to select 'meet accreditation requirements' and 'monitor effectiveness of programmes', 'guide planning and improvements efforts', and 'increase accountability' as purposes of assessment. Pubic universities were more likely to utilise 'score on standardised tests' as an assessment instrument than private universities and to identify legislators, advisory councils, and the business community as stakeholders. Private universities were more likely than public universities to assess lifelong learning, and reflective thinking.

There was a statistically significant relationship between the type of accreditation held by schools of business and the purposes of assessment and skills/competencies skilled. If business schools had AACSB or ACBSP accreditation, there was significantly greater use of assessment data for purposes of meeting accreditation agency requirements, while ACBSP and regionally accredited schools were more likely to use assessment for the purpose of increasing accountability. Finally, schools that are accredited by ministry of higher education were at least twice more likely than other 
schools to use assessment to attract equipment and financial resources. There were no statistically significant relationships between the type of accreditation and usages of assessment. AACSB and regionally accredited colleges were more likely to have university and college of business assessment programmes. AACSB and ACBSP were more likely to utilise alumni surveys and standardised tests as assessment instruments while regionally accredited were more likely to utilise focus groups. While colleges that are accredited by ministry of higher education were the least concerned about faculty as a stakeholder, While AACSB and ACBSP accredited colleges of business were more likely to identify administrators, employers, alumni, and business community as key stakeholders for assessment, regionally accredited colleges were more concerned with current students. AACSB and regionally accredited schools of business were more likely to assess communication skills and global issues while ACBSP accredited schools were more likely to assess professional knowledge.

Majority of the respondents (61\%) reported conducting assessment annually and $19 \%$ had assessment semi-annually. Sixty-four percent of AACSB accredited colleges of business conducted assessment activities annually compared to $75 \%$ of ACBSP accredited colleges of business, $57 \%$ of regionally accredited colleges, and $45 \%$ of universities accredited by ministry of higher education. AACSB accredited colleges reported associate dean as responsible for college assessment activities while ACBSP accredited indicated dean of their college and department chairs as being equally responsible. Regionally accredited colleges indicted assessment committee as responsible while colleges that are accredited by ministry of higher education reported their dean as being the responsible person for assessment.

Finally, there were statistically significant relation between location of institution (USA vs. Middle East) and usages and purposes of assessment as well as skills/competencies assessed.

While $94 \%$ of US institutions reported 'curriculum changes' as a major usage of assessment, $80 \%$ of Middle East institutions indicated such usage. While $60 \%$ of Middle East institutions selected 'meet responsibility to public' as a major usage of assessment, only $41 \%$ of US institutions identified such usage. US institutions were more likely than Middle East universities to identify 'meet accreditation agency requirements', 'monitor effectiveness of programmes', 'guide planning and improvements efforts', and 'increase accountability' as major purposes of assessment. Middle Eastern universities, however, were almost twice more likely than US universities to identify 'attract better students' and three times more likely to identify 'attract equipment and other financial resources' as major purposes of assessment. US universities were more likely than Middle East institution to assess communication skills, professional knowledge, and global issues while Middle East institutions were more likely to assess lifelong learning than US institutions. While $65 \%$ of US universities reported assessment activities annually, only $47 \%$ of Middle East institutions assessed their curriculum annually. US universities were more likely to identify faculty, current and prospective students, legislators, and business community, and employers as major stakeholders than Middle East institutions. Almost half $(49 \%)$ of Middle East institutions are doctorate granting institutions compared to only $21 \%$ of US universities. While $83 \%$ of US institutions are accredited by AACSB only $17 \%$ of Middle East are accredited by the same organisation. Seventy-nine percent of US institutions reported an assessment programme at the university level compared to $60 \%$ of Middle East institutions. US institutions identified an assessment director as the 
person responsible for the university assessment while the Middle East institutions identified the dean of the colleges are primary responsible. Almost all US institutions (97\%) reported the existence of an assessment programme at the colleges of business level, compared to $76 \%$ of Middle Eastern institutions. US institutions identified associate dean as the person responsible for the college of business assessment programme while Middle East institutions identified the dean of the college as primary responsible. While over $90 \%$ of all universities, regardless of location, reported the existence of programme learning objectives, $96 \%$ of the USA (compared to $80 \%$ Middle East) actually assessed their learning objectives. There was significant difference in the costs of assessment between the USA and Middle East institutions. US institutions reported costs of assessment to be between $\$ 5001$ and $\$ 10,000$ while Middle East institutions reported costs of $\$ 10,001$ to $\$ 20,000$ annually. Seventy-nine percent of Middle East institutions and 53\% of US institutions reported the existence of a budget allocation for assessment activities. Of those reported a budget allocation, $82 \%$ of US institutions reported budget allocation for assessment as part of their college budget while $47 \%$ of Middle East universities indicated budget allocation as part of their university budget. Finally, While US institutions were twice more likely than Middle East universities to utilise 'focus groups', and 'score on standardised tests' as an assessment instrument, Middle East institution utilised faculty surveys more than US universities. Sixty-five percent of US institutions and $28 \%$ of Middle East institutions reported the utilisation of standardised tests as assessment instrument.

Finally, a comparison of the stakeholders of assessment of theUSA and Middle East institutions is completed in Table 5. While the USA and Middle East institutions consider faculty, employers, current students, business community, and alumni to the top five stakeholders, US institutions ranked faculty higher than Middle East institutions.

Table 5 Stakeholders of assessment (USA vs. Middle East institutions)

\begin{tabular}{lcc}
\hline Stakeholders of assessment & $\begin{array}{c}\text { USA institutions } \\
\text { (percentage of respondents) }\end{array}$ & $\begin{array}{c}\text { Middle East institutions } \\
\text { (percentage of respondents) }\end{array}$ \\
\hline Faculty & 96 & 72 \\
Employers & 91 & 76 \\
Current students & 91 & 76 \\
Business community & 83 & 60 \\
Alumni & 76 & 60 \\
Administration & 71 & 56 \\
Prospective students & 64 & 44 \\
Advisory council & 43 & 28 \\
Staff & 38 & 44 \\
Legislators & 34 & 8 \\
\hline
\end{tabular}

\section{Summary and conclusions}

This study examined the assessment programmes used by various schools of business located in the USA and the Middle East. Relatively few statistically significant differences in responses were apparent. Compared to other colleges and universities, 
Middle Eastern institutions are more concerned with 'meeting responsibilities to public' than US institutions. Middle Eastern institutions were more likely than US universities to identify 'attract better students' and 'attract equipment and other financial resources' as major purposes of assessment. While $65 \%$ of US institutions reported assessment activities annually, only $25 \%$ of Middle Eastern universities assessed their curriculum annually. Compared to other colleges, private institutions were more likely to assess lifelong learning and reflective thinking. AACSB accredited colleges of business were more likely to have curriculum/programme objectives and were more likely to have plans to improve/revise assessment process. Schools of business with AACSB accreditation were more likely to assess communication skills than other schools.

Similar surveys were conducted in 1999 (Hindi and Miller, 2000b) with significant differences in results. Table 6 summarises the differences between 1999 and 2007. For the year 2007, statistics were tabulated for US universities and for Middle East universities separately. For example, US universities seem to be more involved with assessment as evident by $79 \%$ of universities surveyed in 2007 indicated they had a formal assessment programme, compared to $76 \%$ during 1999 . Colleges of business are now more engaged in assessment. During 2007, 97\% of business schools reported a formal assessment programme compared to $84 \%$ in 1999 . Cost of assessment seems to be increasing as well. In 1999, 50\% of deans reported their assessment activities cost less than $\$ 5,000$ annually compared to $24 \%$ in 2007 . Although almost the same percentage of colleges of business in 2007 has specific curriculum/programme objectives as they did in 1999 (92\% in 2007 and $88 \%$ in 1999), significantly more US colleges actually assess their objectives. During 2007, 87\% of colleges indicated they assess the specific curriculum/programme, objectives compared to $64 \%$ in 1999 . Usages and purposes of assessment seem to have been consistent during this period of time. During the past eight years, more emphasis seems to be placed on communications skills, professional knowledge, critical thinking, technology/computer usage, and global issues. As far as purposes of assessment, US institutions in 2007 seem to pay more attention to meet accreditation agency requirements, and increase accountability and less emphasis on attracting equipment and other financial resources.

Business school deans and associate deans play major roles in the assessment process. To improve/revise assessment programmes, deans planned to continuously review and improve assessment process, increase formality of assessment programme, incorporate more direct measures of assessment, close the loop, and assess learning outcomes. Colleges of business are relaying heavily on course-embedded measures, followed by indirect measures of assessment (surveys). A variety of instruments was used in assessment processes. These included scores on student evaluation of faculty, alumni survey, exit survey, employer surveys, and scores on standardised tests.

Curriculum and instructional changes were the top-ranked uses for assessment outcomes. As viewed by school of business deans, the most prevalent purposes of assessment were to meet accreditation requirements, monitor programme effectiveness, and guide planning/improvement efforts. Faculty, current students, employers, business community, alumni, and administrators were considered to be major stakeholders of schools of business. Primary skills measured in assessment included communication skills, critical thinking, professional knowledge, technology/computer usage, and global issues. 
Table 6 Summary of assessment results: 1999 vs. 2007 (USA)

\begin{tabular}{|c|c|c|c|}
\hline \multirow[t]{2}{*}{ Assessment item } & \multirow{2}{*}{$\begin{array}{c}1999 \text { percentage } \\
\text { of responses } \\
\text { (USA) }\end{array}$} & \multicolumn{2}{|c|}{$\begin{array}{c}2007 \text { percentage of } \\
\text { responses }\end{array}$} \\
\hline & & USA & Middle East \\
\hline Existence of university assessment programme & $76 \%$ & $79 \%$ & $60 \%$ \\
\hline $\begin{array}{l}\text { Existence of college of business assessment } \\
\text { programme }\end{array}$ & 84 & 97 & 54 \\
\hline \multicolumn{4}{|l|}{ Annual costs of assessment } \\
\hline Less than $\$ 5,000$ & 50 & 24 & 35 \\
\hline$\$ 5,001-\$ 10,000$ & 17 & 35 & 12 \\
\hline$\$ 10,000-\$ 20,000$ & 11 & 16 & 53 \\
\hline Greater than $\$ 20,000$ & 6.6 & 25 & 0 \\
\hline $\begin{array}{l}\text { Existence of specific curriculum/programme } \\
\text { objectives }\end{array}$ & 88 & 92 & 71 \\
\hline $\begin{array}{l}\text { Assessment of specific curriculum/programme } \\
\text { objectives }\end{array}$ & 64 & 87 & 57 \\
\hline \multicolumn{4}{|l|}{ Uses of assessment results } \\
\hline Curricular changes & 89 & 94 & 57 \\
\hline Instructional changes & 80 & 85 & 51 \\
\hline Meet responsibility to students & 62 & 57 & 46 \\
\hline Meet responsibility to public & 41 & 41 & 43 \\
\hline \multicolumn{4}{|l|}{ Skills/competencies assessed } \\
\hline Communication skills & 79 & 96 & 57 \\
\hline Professional knowledge & 73 & 88 & 46 \\
\hline Critical thinking & 73 & 88 & 60 \\
\hline Technology/computer usage & 67 & 76 & 51 \\
\hline Global issues & 52 & 75 & 37 \\
\hline Problem solving & 67 & 71 & 43 \\
\hline Professional integrity/ethics & 48 & 71 & 40 \\
\hline Interpersonal skills & 66 & 53 & 34 \\
\hline Lifelong learning & 19 & 20 & 40 \\
\hline \multicolumn{4}{|l|}{ Purposes of assessment: } \\
\hline Monitor the effectiveness of the programme & 91 & 92 & 51 \\
\hline Meet accreditation agency requirements & 78 & 92 & 54 \\
\hline Guide planning and improvement efforts & 88 & 88 & 51 \\
\hline Increase accountability & 59 & 73 & 31 \\
\hline Provide information relevant to policies & 43 & 42 & 31 \\
\hline Attract better students & 34 & 32 & 37 \\
\hline Attract equipment/financial resources & 22 & 10 & 20 \\
\hline
\end{tabular}




\section{Acknowledgements}

This publication was made possible by support from Qatar University. Its contents are solely the responsibility of the authors and do not necessarily represent the official views of Qatar University.

\section{References}

AACSB International - The Association to Advance Collegiate Schools of Business (2004) Overview of Assessment, AACSB, Tampa, FL, available at http://www.aacsb.edu/resource_centers/assessment/overview-process.asp (accessed on 13 November 2006).

AACSB International - The Association to Advance Collegiate Schools of Business (2005) 'Assessment of student learning in business schools: best practices each step of the way', in Kathryn Martell and Thomas Calderon (Eds.): .Assessment on the Discipline, Vol. 1, No. 1.

AACSB International - The Association to Advance Collegiate Schools of Business (AACSB) (2002) 'Management education at risk', Report of the management education task force, AACSB, St. Louis, Missouri, August, pp.19-22.

Abouchedid, K. and Eid, G. (2004) 'E-Learning challenges in the arab world: revelations from a case study profile', Quality Assurance in Education, Vol. 12, No. 1, pp.15-27.

Abouchedid, K. and Nasser, R. (2002) 'Assuring Quality service in higher education: registration and advising attitudes in a private university in Lebanon', Quality Assurance in Education, Vol. 10, No. 4, pp.198-206.

Angelo, T.A. (1995) 'Reassessing assessment', AAHE Bulletin, Vol. 47, No. 8, pp.10-13.

Apostolou, B. (1999) 'Outcomes assessment', Issues in Accounting Education, February, Vol. 14, No. 1, pp.177-197.

Bender, B.E. and Schuh, J.H. (2002) 'Editorial notes', New Directions for Higher Education, Vol. 118, p.1.

Black, H. and Duhon, D. (2003) 'Evaluating and improving student achievement in business programs: the effective use of standardised assessment tests', Journal of Education for Business, November-December, Vol. 79, No. 2, pp.90-98.

Bock, R., Mislevy, R. and Woodson, C. (1982) 'The next stage in educational assessment', Educational Researcher, March, Vol. 11, No. 3, pp.4-11, 16.

Dietel, R., Herman, J. and Knuth, R. (1991) What Does Research Say About Assessment?, North Central Regional Educational Laboratory, Oak Brook, Illinois, available at http://www.ncrel.org/ (accessed on 17 December 2004).

Donald, J. and Denison, D. (2001) 'Quality assessment of university students', The Journal of Higher Education, July-August, Vol. 72, No. 4, pp.478-502.

Evans, C. (2002) 'Understanding assessment', Delta Pi Epsilon Journal, Winter, Vol. 44, No. 1, pp.3-12.

Gainen, J. and Locatelli, P. (1995) Assessment of the New Curriculum: A Guide for professional Accounting Programs, American Accounting Association, Sarasota, Florida, p.3.

Harwood, E. and Cohen, J. (1999) 'Classroom assessment: educational and research opportunities', Issues in Accounting Education, November, Vol. 14, No. 4, pp.691-724.

Hatfield, S. and Gorman, K. (2000) 'Assessment in education - the past, present, and future', in J. Rucker (Ed.): Assessment in Business Education National Business Education Association Yearbook, No. 38, pp.1-10, National Business Education Association, Reston, Virginia.

Hazeldine, M. and Munilla, L. (2004) 'The 2003 AACSB accreditation standards and implications for business faculty: a short note', Journal of Education for Business, September-October, Vol. 80, No. 1, pp.29-34. 
Henninger, E. (1994) 'Outcomes assessment: the role of business school and program accrediting agencies', Journal of Education for Business, May, Vol. 69, No. 5, pp.296-298.

Hindi, N. and Miller, D. (2000a) 'A survey of assessment practices in accounting departments of colleges and universities', Journal of Education for Business, May-June, Vol. 75, No. 5, pp.286-290.

Hindi, N. and Miller, D. (2000b) 'A survey of assessment practices in schools of business', Central Business Review, Winter, Vol. 19, No. 1, pp.13-18.

James, R. (2003) 'Academic standards and the assessment of student learning: some current issues', Tertiary Education and Management, September, Vol. 9, No. 3, pp.187-198.

Kimmell, S., Marquette, R. and Olsen, D. (1998) 'Outcomes assessment programs: historical perspective and state of the art', Issues in Accounting Education, November, Vol. 13, No. 4, pp.851-868.

Lambrecht, J. (2000) 'Characteristics of good assessment', in J. Rucker (Ed.): Assessment in Business Education National Business Education Association Yearbook, No. 38, pp.25-38, National Business Education Association, Reston, Virginia.

Linn, R. (1993) 'Educational assessment: expanded expectations and challenges', Educational Evaluation and Policy Analysis, Spring, Vol. 15, No. 1, pp.1-16.

Michlitsch, J. and Sidle, M. (2002) 'Assessing student learning outcomes: a comparative study of techniques used in business school disciplines', Journal of Education for Business, January-February, Vol. 77, No. 3, pp.125-130.

Miller, M. (1999) 'Classroom assessment and university accountability', Journal of Education for Business, November-December, Vol. 75, No. 2, pp.94-98.

Nasser, R. and Abouchedid, K. (2005) 'Graduates' perception of university training in light of occupational attainment and university type' the case of Lebanon', Education + Training, Vol. 47, No. 2, pp.124-133.

Peterson, M. and Einarson, M. (2001) 'What are colleges doing about student assessment?', The Journal of Higher Education, November-December, Vol. 72, No. 6, pp.629-669.

Pfeffer, J. (2002) 'Competitive advantage through people', in J. Henry and D. Mayle (Eds.): Managing Innovation and Change, p.3, The Open University Business School and Sage Publications, London.

Pritchard, R., Potter, G. and Saccucci, M. (2004) 'The selection of a business major: elements influencing student choice and implications for outcomes assessment', Journal of Education for Business, January-February, Vol. 79, No. 3, pp.152-156.

Riggio, R., Mayes, B. and Schleicher, D. (2003) 'Using assessment center methods for measuring undergraduate business student outcomes', Journal of Management Inquiry, March, Vol. 12, No. 1, pp.68-78.

Roller, R., Andrews, B. and Bovee, S. (2003) 'Specialized accreditation of business schools: A comparison of alternative costs, benefits, and motivations', Journal of Education for Business, March-April, Vol. 78, No. 4, pp.197-204.

Shaw, K.E., Badri, A and Hukul, A. (1995) 'Management concerns in the United Arab Emirates state schools', International Journal of Educational Management, Vol. 9, No. 4, pp.8-13.

Stivers, B., Campbell, J. and Hermanson, H. (2000) 'An assessment program for accounting: design, implementation, and reflection', Issues in Accounting Education, November, Vol. 15, No. 4, pp.553-581.

Terenzini, P. (1989) 'Assessment with open eyes: pitfalls in studying student outcomes', The Journal of Higher Education, November-December, Vol. 60, No. 6, pp.644-664. 


\section{Appendix A}

\section{Assessment survey - school/college of business deans}

1 What is the highest academic degree offered by your school/college of business?
Doctorate
$\square$ Masters
$\square$ Bachelors

2 Your institution is:

$\square$ Public

$\square$ Private

3 Your school/college of business is accredited by:

$\square$ AACSB International - the Association to Advance Collegiate Schools of Business

$\square$ Association of Collegiate Business Schools and Programmes (ACBSP)

$\square$ Regional Accreditation (i.e., North Central, Southern,.., etc.)

$\square$ Ministry of Higher Education

If AACSB accredited, does the accounting programme have a separate accreditation?
$\square$ Yes
$\square$ No

4 Does your university have a formal assessment programme?

$\square$ Yes $\square$ No

(a) If so, which academic professional has the major responsibility for the administration of your assessment programme?
$\square$ Director of assessment
$\square$ Vice president
$\square$ Dean, School of Business
Department Chairs
Associate Dean
$\square$ Other

(b) If so, how often is the assessment conducted?

(Please specify)

5 Does your school of business have a formal assessment programme?

$\square$ Yes $\quad \square$ No

(a) If so, which academic professional has the major responsibility for the administration of your assessment programme?

$\square$ Director of assessment

$\square$ Dean, School of Business

$\square$ Assessment Committee

$\square$ Associate Dean

$\square$ Department Chairs

$\square$ Other

(Please specify)

(b) If so, what is the approximate annual costs for your school of business assessment process (faculty time, postage, analysis, ..., etc.)?
$\square$ Less than $\$ 5,000$
$\$ 5,001-\$ 10,000$
$\$ 10,001-\$ 20,000$
$\square$ Over $\$ 20,000$

(c) If so, is there any budget allocated for assessment activities? $\square$ Yes $\square$ No

(d) If a budget is allocated, is it part of:

$\square$ College budget

$\square$ Department budget

University budget 
6 Do you have specified curriculum/programme objectives (learning outcomes) for your core courses?
$\square$ Yes
No. If yes, do you assess them?
Yes $\square$ No

7 Which of the following approaches of assessment does your school/college of business use? (Check all that apply)

$\square$ Student selection (admission criteria)

Course-embedded measurement (projects/cases/assignment/readings)

$\square$ Demonstration through stand-alone testing or performance (i.e., ETS major field test, in house exit exam, CPA, CMA)

$\square$ Indirect measures (surveys of alumni, employers, graduating seniors)

Other (Please specify)

8 Which of the following instruments does your school/college of business use? (Check all that apply)

$\square$ Alumni survey

$\square$ Student evaluation of faculty

$\square$ Focus groups Employer survey

$\square$ Faculty survey

Score on standardised tests (i.e., CPA, CMA, GMAT, GRE, ETS major field test)

$\square$ Other (Please specify)

9 How does your school/college of business use the results from assessment? (Check all that apply)

$\square$ Curricular changes

$\square$ Instructional changes

$\square$ Meet responsibility to students

$\square$ Meet responsibility to the public

Other (Please specify)

10 What is (are) the purpose(s) of assessment? (Check all that apply)

$\square$ Meet accreditation agency requirements

$\square$ Monitor the effectiveness of the programmes

$\square$ Guide planning and improvement efforts

$\square$ Attract better students

$\square$ Provide information relevant to policies

$\square$ Increase accountability

$\square$ Attract equipment and/or financial resources

Other (Please specify)

11 Who do you consider to be the stakeholders in the assessment process? (Check all that apply)

$\square$ Faculty

Administrators

Employers

$\square$ Current students

$\square$ Staff

$\square$ Alumni

$\square$ Legislators

Business community

$\square$ Prospective students

Programme advisory councils

Other (Please specify) 
12 What skills/competencies do you assess? (Check all that apply)

$\square$ Communication skills

Lifelong learning

$\square$ Critical thinking

$\square$ Global issues

$\square$ Multicultural/diversity

Reflective thinking

Technology/computer usage

Professional integrity (ethics)

Problem solving

Interpersonal skills (teamwork, leadership)

Other (Please specify)

13 What do you consider the major strength(s) of your assessment programme?

14 What do you consider the major weakness(es) of your assessment programme?

15 Do you have any plans to improve/revise the assessment process?

$\square$ Yes $\square$ No

If so, what are your plans? 